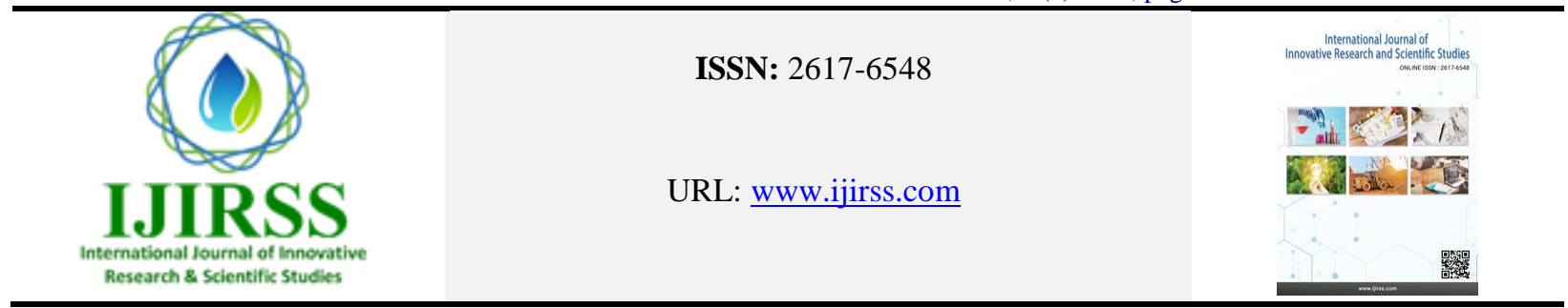

\title{
Assessment of Badakhshan Climatic Condition for Production and Marketing of Saffron
}

\author{
Abdul Sami Wafa \\ ${ }^{1}$ Department of economic and extension, Faculty of Agriculture, Baghlan University, Baghlan, Afghanistan
}

(Email: samiwafa100@gmail.com)

\begin{abstract}
A research was conducted in 2019 to assess the favorability of Badakhshan climatic condition for production and marketing of saffron. The data was collected through questionnaires from 30 participants of Badakhshan saffron farmers, specialists, professors, school of economics and agriculture departments. According to the average results of the total respondents it is said that climatic condition of Badakhshan is $76.2 \%$ favorable for saffron cultivation. The marketing evaluation is said that $23 \%$ of Badakhshan saffron is consumed at home, $40 \%$ is sold in local market, $20 \%$ percent is sold in national market and $17 \%$ is sold in international markets. $36 \%$ respondents believe that saffron has very little effect, and $57 \%$ said that it has little impact and $7 \%$ of the respondent answered that saffron has great effects on the farmers' income in Badakhshan. Therefore, it is concluded that the Badakhshan climatic condition is favorable for production and marketing of saffron but it requires government and relevant agriculture departments and NGO's to supply saffron roots, focus on farmers training and marketing of saffron to raise its quality level and increase the farmer's income in Badakhshan.
\end{abstract}

Keywords: Saffron, Climatic Condition, Marketing, Badakhshan.

DOI: 10.53894 /ijirss.v4i1.53

Funding: This study received no specific financial support.

History: Received: 29 December 2020/Revised: 26 January 2021/Accepted: 19 February 2021/Published: 3 March 2021

Licensed: This work is licensed under a Creative Commons Attribution 4.0 License $($ (c) $)$ EY

Competing Interests: The author declares that there are no conflicts of interests regarding the publication of this paper.

Transparency: The author confirm that the manuscript is an honest, accurate, and transparent account of the study was reported; that no vital features of the study have been omitted; and that any discrepancies from the study as planned have been explained.

Ethical: This study follows all ethical practices during writing.

\section{Introduction}

Saffron is an amazing, beautiful and fragrant plant; these traits have attracted the attention of our ancestors and so become the reminder of ancient history [1]. Among the tens of thousands of medicinal plants, saffron is the only one that has been equated to a home pharmacy. Saffron is an exceptional plant that its properties and wide range of applications as a medicine and its treatment is a great wonder [2]. The per capita consumption of saffron in the world is only 14 milligrams. The main reason for this low per capita consumption of saffron globally is the low supply of saffron in the world; as well as fraud in the supply of this product in domestic and foreign markets [2]. With the initiative of migrant and local farmers, saffron cultivation started only in 1992 in Afghanistan. Saffron has grown in such a way in this climate that it seems this plant has returned to its native land [3]. Climatic conditions, immaculate soil for saffron cultivation, and the toiling people of this land have all joined hands to produce the highest quality saffron and offer it to the world [4]. Emerging saffron cultivation in Afghanistan is developing rapidly this time. In different parts of Afghanistan, various organizations and institutions want to replace saffron with other native plants, which promises to further promote and expand the production of this precious plant in the country [5]. Afghanistan is one of the arid regions of the world where frequent droughts along with water shortages are one of the major obstacles to agricultural and livestock development. 
Thus, it is necessary to reduce the adverse effects of drought, prevent financial losses to farmers, and raise the income of the agricultural sector along with planting promoted crops, new crops that can tolerate dry climatic conditions should also be introduced and promoted. Experiences of the past few years show that saffron can be one of these valuable crops [6]. Afghanistan's saffron production has increased by 22 percent this year compared to last year; and the areas that cultivate saffron has increased by about 20 percent. Afghanistan's saffron is currently sold at 90,000 AFN. per kilogram in the domestic market, which was 45,000 AFN. per kilogram last year [7]. In international markets however, it is sold for $\$ 1400$ to $\$ 2000$ per kilogram $[4,8]$. For four consecutive years, Afghanistan has been ranked first in the world in terms of quality and taste of saffron, and has ranked third in terms of production and exports after Iran and Spain [9-11]. As it has been stated, the climatic conditions of Afghanistan are favorable for saffron cultivation, and efforts are being made to promote and spread this valuable plant throughout the country. The aim of this research tried to find out more about the climatic conditions of Badakhshan province to promote this valuable plant.

\section{Research Methodology}

In this research, correlation and consonant methods have been used. A mixture of desk research and field research was used to conduct this study. 30 questionnaires were distributed to Badakhshan Agriculture and Economics Faculties, professors and lecturers along with the directorate of Agriculture of the province. The information was collected based on their responses. Each questionnaire contained two parts. A and B which the first part (A) was short questions and second part (B) was open questions related the topic. Practical results are obtained from the questionnaires reflect the perspective of farmers, specialists, professors of Badakhshan school of economics and agriculture. According to analyses of the collected data, we evaluated whether the Badakhshan climate is desirable for crop cultivation of Saffron; issues related to saffron marketing, and has it affected the people and province's living conditions or not?

\section{Results}

Practical results are obtained from the questionnaires. Through questionnaires, we have tried to collect relevant information from the perspective of specialized farmers, professors of economics and agriculture faculties, and by analyzing this information, we can see whether the climate is favorable for saffron cultivation? How has saffron been marketed? Has it affected the income of people in this province or not? Through the results, we will present a series of solutions and suggestions to improve and enhance the level of saffron production in Afghanistan-Badakhshan province. Table 1 shows the classification of the 30 participant's responses into four categories (A, B, C and D). The alphabet (A) states the higher response, while the $\mathrm{D}$ shows the lowest response in table. We hope that the actual results obtained and the solutions and suggestions provided will be useful.

Table-1.

Participant responses to the desirability of climate for saffron planting in Badakhshan.

\begin{tabular}{c|c|c}
\hline Option & Number of responses & Percentage \\
\hline A & 11 & $37 \%$ \\
\hline B & 9 & $30 \%$ \\
\hline C & 9 & $30 \%$ \\
\hline D & 1 & $3 \%$ \\
\hline Total & 30 & $100 \%$ \\
\hline
\end{tabular}

According to the study $37 \%$ of respondents stated that the saffron cultivation is $50 \%$ adoptable under climate of Badakhshan, while the remaining $30 \%, 30 \%$ and $3 \%$ of the respondents believe that the saffron cultivation is adoptable $75 \%, 85 \%$ and $95 \%$ under climatic condition of Badakhshan respectively. Thus, we can infer that the climate in Badakhshan is favorable for saffron cultivation.

Table-2.

Badakhshan's saffron marketing.

\begin{tabular}{l|c|c}
\multicolumn{1}{c|}{ Option } & Number of responses & Percentage \\
\hline Home & 7 & $23 \%$ \\
\hline Provincial Market & 12 & $40 \%$ \\
\hline National Market & 6 & $20 \%$ \\
\hline International Market & 5 & $17 \%$ \\
\hline Total & 30 & $100 \%$ \\
\hline
\end{tabular}

As shown in Table 2 about 23\% of respondents believe that saffron produced in Badakhshan is consumed at home. Forty percent of respondents believe that produced saffron is sold in local markets. $20 \%$ of respondents believe that saffron produced in Badakhshan is sold in national markets; and 17\% of respondents believe that saffron produced in Badakhshan is sold in international markets. Therefore, it can be concluded that although saffron cultivation has no ancient history in Badakhshan, and not cultivated as a promotional plant among farmers; this crop still mostly sells in local markets in the province, in national markets in the country, and a small amount in goes to the international markets. 
Table-3.

Percentage of domestic and foreign actors' role in promoting and cultivating saffron in Badakhshan.

\begin{tabular}{l|c|c}
\hline \multicolumn{1}{c|}{ Option } & Number of responses & Percentage \\
\hline Thirty percent & 15 & $50 \%$ \\
\hline Fifty percent & 11 & $37 \%$ \\
\hline Seventy percent & 3 & $10 \%$ \\
\hline Ninety percent & 1 & $3 \%$ \\
\hline Total & 30 & $100 \%$ \\
\hline
\end{tabular}

As shown in Table 3 about $50 \%$ of respondents believe that the domestic and foreign actors have played a $30 \%$ role in promoting saffron cultivation in Badakhshan. 37\% of respondents believe that the domestic and foreign actors have played $50 \%$ role in promoting saffron cultivation in Badakhshan. $7 \%$ of respondents believe that the domestic and foreign actors have played a 70\% role in promoting saffron cultivation in Badakhshan. And 3\% of respondents believe that the domestic and foreign actors have played a $90 \%$ role in promoting saffron cultivation in Badakhshan. It can be concluded that both domestic and foreign actors have not done much to promote saffron cultivation in Badakhshan.

Table-4.

Percentage of sales of saffron produced in Badakhshan in the markets.

\begin{tabular}{l|c|c}
\hline \multicolumn{1}{c|}{ Option } & Number of responses & Percentage \\
\hline Seventy percent & 4 & $14 \%$ \\
\hline Fifty percent & 22 & $73 \%$ \\
\hline Eighty five percent & 4 & $13 \%$ \\
\hline Ninety five percent & 0 & $0 \%$ \\
\hline Total & 30 & $100 \%$ \\
\hline
\end{tabular}

Table 4 indicates that $14 \%$ of the respondents believe that $70 \%$ of saffron produced in Badakhshan is sold in the markets. $73 \%$ of the respondents believe that $50 \%$ of the saffron produced in Badakhshan province is sold in the markets. And $13 \%$ of the respondents believe that $95 \%$ of saffron produced in Badakhshan is sold in the markets. Therefore, it can be concluded that relatively less than half of the saffron produced in Badakhshan is consumed in homes.

Table-5.

Level of saffron cultivation impact on the farmers' income in Badakhshan.

\begin{tabular}{l|c|c}
\hline \multicolumn{1}{c|}{ Option } & Number of responses & Percentage \\
\hline Very few & 11 & $75 \%$ \\
\hline Few & 17 & $15 \%$ \\
\hline Much & 2 & $10 \%$ \\
\hline
\end{tabular}

Table 5 shows that $15 \%$ of respondents believe that saffron cultivation has very little effect on the farmers' income in Badakhshan. $75 \%$ of respondents believe that saffron cultivation has little effect on the farmers' income in Badakhshan. The $7 \%$ of the respondents believe that saffron cultivation has a great impact on the farmers' income in Badakhshan. Therefore, it can be concluded that due to the lack of assistance from domestic and foreign actors, and the costs of saffron cultivation, from an income perspective, it has little effect on the farmers' income in Badakhshan.

Note: People's and especially the farmers' awareness level are low, but the agricultural sector has done good in this province to introduce saffron to farmers. The organizations that have been involved in saffron cultivation in this province are Afghan Agha Khan Foundation (AKF), Deutsche Gesellschaft für Internationale Zusammenarbeit (GIZ) and National Horticulture and Livestock Project (NHLP) have planted saffron on about 100-90 acres of land in Badakhshan. The main reasons for the weakness of saffron cultivation and production in Badakhshan are lack of saffron roots, lack of professionals, and lack of farmers' sufficient knowledge in this field.

\section{Discussion}

Saffron is attributed as the "red gold" among farmers, producers, saffron specialists, and traders since long time ago; this crop has become popular and has grown substantially in Afghanistan. Farmers have played a key role in promoting this crop. Officials at the Ministry of Agriculture, Irrigation, and Livestock claim that saffron will be more prevalent in most provinces' climate. Saffron is considered as one of the most strategically important agricultural crops in Afghanistan, thus it is necessary for the government to develop a regular and specific plan for further growth and expansion of this crop so that the process of promoting and developing saffron in northeastern Afghanistan, especially Badakhshan goes well. Lack of such a regular plan to promote saffron in some projects, in addition to the failure and waste of the country's allocated saffron funds has prevented the development of saffron cultivation through the loss of saffron roots. A quality control committee of 8 people has been established in the Department of Agriculture of Herat province to work to improve the quality of saffron; so that Afghanistan's saffron can compete with major saffron producers in the world and find its due place in the global market. In Herat, currently, there are more than 37 saffron associations, 52 private companies and 9000 farmers, who have used experiences of saffron experts and are promoting cultivation of this crop in the western zone. These experiences can be used to expand saffron production in the northeastern zone, especially Badakhshan as well. The 
results obtained from the questionnaires show that Badakhshan is favorable for saffron production. The aid and measures taken by the government and other organizations are not enough; more measures must be taken to expand the cultivation of this crop to other provinces that have suitable climate for the cultivation of this crop. Today, unemployment affecting most families in the country, is a major problem for the government. Due to this, creating employment and economic prosperity is an important economic priority of the government. There are several factors in creating employment; one of the most important strategies is to identify job-creating sectors and invest on them. Agriculture has a significant role in the economy and society of Afghanistan; because a large number of people directly and indirectly rely on agricultural income for livelihood; in which saffron can be cultivated as an alternative crop with a high capacity to attract manpower.

\section{Conclusion}

Saffron is an amazing, beautiful, fragrant and medicinal plant which is cultivated as valuable crops in different parts of Afghanistan since 1992. This crop is also grown in Badakhshan province and $76.2 \%$ participants believe that climatic condition of Badakhshan is favorable for saffron cultivation. The marketing evaluation is said that the highest percentages (40\%) of saffron produced in Badakhshan is sold in local markets, while the lowest percentages (17\%) is sold international market and remaining $43 \%$ is either consumed at home (23\%) or is sold in national market (23\%). Majority of the participants $(57 \%)$ believe that saffron has little impacts on the farmers' income while $36 \%$ and $7 \%$ of the participants believe that saffron has very little and great impacts on the farmers' income in Badakhshan respectively. Therefore, it is concluded that the Badakhshan climatic condition is favorable for production and marketing of saffron but it requires government and relevant agriculture departments and NGO's to supply saffron roots, focus on farmers training and marketing of saffron to raise its quality level and increase the farmer's income in Badakhshan.

\section{Suggestions}

1. Focus on marketing saffron and raise its quality level

2. It is necessary to install a saffron quality control laboratory by the government in the northeastern provinces due to physical, chemical and microbiological tests

3. Train marketing specialists through short-term exchanges abroad in order to expand saffron production in Afghanistan, especially in the northeastern provinces

4. Raise awareness of farmers about the benefits and high income possibilities to encourage saffron cultivation

5. Organize training courses for farmers so that they know how to cultivate saffron properly, which will have a great impact on the quality of saffron production

6. Support farmers with financial assistance, especially loans

7. Necessary facilities to produce high quality saffron should be provided for farmers

8. The government should distribute saffron roots in areas that are considered favorable in terms of climate and soil.

\section{References}

[1] M. H. Aslami and A. J. Zahed, "Manual for cultivating saffron for the facilitators of the farmer's school," 2017.

[2] S. Maqsoodi, Agriculture, industry, nutrition and treatment: Elm-e-Keshavarzi Publication, 2012.

[3] B. A. Nusrat, Saffron (cultivating techniques, breeding, storing, and processing), 1st ed. Herat: Aslami Production, 2013.

[4] Y. Abbasali, Saffron production (Medicinal properties of Saffron), 2nd ed.: Kankash publication, 2016.

[5] Y. Abbasali and Z. Shujaee, "Importance of saffron in Iran and in the world," 2013.

[6] M. Astaki, A guide to cultivation of saffron in Iran: Marz Danesh Publication, 2016.

[7] H. Ibrahimzada, Iran saffron: Tehran University, 2014.

[8] M. H. Abrishemi, Saffron from long back till today: Amir Kabir Publication, 2011.

[9] M. T. Yadgar, Introduction of heart saffron: Agriculture Training and Extension Publication, 2014.

[10] H. M. Aslami, Saffron production, marketing and processing, holland training course notes: GES Company and Agro ECO Institute, 2006.

[11] H. M. Aslami, "Saffron from planting to harvesting to processing," presented at the 1st National Conference on Saffron, Heart, Afghanistan, 2006. 